\title{
Adopsi Sebagai Upaya Melindungi Hak-Hak Anak Dalam Perspektif Hukum Islam
}

\author{
Karimatul Ummah
}

$\therefore$

\section{Abstrak}

Adoption is intended to protect the rights of the children toward their future. However, adoption does not automatically change the legal status of the adopted child to be some one's own flesh and blood. The legal status of adopted child to have the right of inheritance depends on what kinds of legal systems used to resolve the inheritance. In Islamic Law Compilation adopted child is not the heir, but he has a right to obtain the will (wasiat wajibah).

\section{Pendahuluan}

Adopsi merupakan istilah yang belakangan marak dibicarakan menyusul terjadinya badai tsunami di Aceh dan Sumatra Utara. Keinginan dari berbagai pihak untuk memperhatikan masa depan anak-anak korban bencana tersebut menjadi alasan untuk melakukan adopsi. Namun dalam kenyataannya, keinginan tersebut tidak mudah untuk dipenuhi menyusul adanya kebijakan dari pemerintah untuk tidak membawa anak-anak korban tsunami keluar dari wilayah bencana. $^{\prime}$

Kebijakan pemerintah dalam mensikapi anak-anak korban tsunami tidak saja dilakukan oleh pemerintah Indonesia, beberapa negara korban tsunami juga membuat kebijakan terkait keberadaan anak-anak. Sebut saja india, melaiui Direktur Pengembangan Wilayah Pinggiran Tamil Nadu, Shanta Sheela Nair menegaskan bahwa pemerintah India tidak akan melonggarkan kebijakan adopsi terhadap siapa saja yang melakukan adopsi dan tujuan melakukan adopsi. Begitu pula pemerintah Srilanka, melalui Coordinator Save the Children Srilanka, Maleec Calyanaratne menyatakan bahwa Pemerintah Srilangka secara tegas melarang adopsi oleh WNA. ${ }^{2}$

Apa yang sebenarnya dihimbau oleh pemerintah negara korban tsunami tersebut cukup beralasan mengingat banyak bukti menunjukkan adanya tujuan menyimpang dari niat di balik adopsi. Dalam realitanya banyak tindakan melawan hukum yang dilakukan oknum dengan berkedok adopsi atau pemeliharaan anak. Sebut saja kegiatan perdagangan anak-anak baik dengan maksud untuk dipelihara atau dipekerjakan dalam berbagai sektor ekonomi sebagai tenaga kerja. Oleh karena itu dalam mensikapi anak-anak korban tsunami ini kemudian pemerintah bersikap

\footnotetext{
1 Kompas, 5 Januari 2005.

${ }^{2}$ Suara Pembaharuan, 5 Januari 2005.
} 
sangat hati-hati.

Sebenarnya masalah adopsi atau pengangkatan anak tidak saja mengenai motivasi pengangkatan anak, tetapi lebih jauh bagaimana perlindungan yang akan diberikan terhadap anak-anak yang diadopsi terutama jauh hari pasca terjadinya pengangkatan anak tersebut. Secara garis besar masalah pengangkatan anak dapat dilihat dari tiga aspek. Pertama, aspek yuridis, yaitu masalah yang timbul berkaitan dengan akibat hukum dari pengangkatan anak. Kedua, aspek sosial yaitu menyangkut efek sosialnya dari perbuatan hukum pengangkatan anak atau adopsi. Ketiga, tinjauan terhadap masalah yang timbul karena berkenaan faktor psikologis, yaitu masalah reaksi kejiwaan yang ditimbulkan karena adopsi tersebut.

Melihat masalah-masalah yang akan muncul berkaitan dengan adanya pengangkatan anak tersebut maka di kalangan ahli hukum Islam terjadi perdebatan. Sebagian mengharamkan adopsi, tetapi sebagian lagi memperbolehkan adopsi demi masa depan anak dengan beberapa pengecualian. Terlepas dari pro kontra kedudukan adopsi tersebut, bagaimana pandangan Hukum Islam tentang adopsi di Indonesia terutama jika dikaitkan dengan upaya pemerintah untuk memberikan perlindungan terhadap hak-hak anak sebagaimana yang diamanatkan oleh Undang Undang Nomor 23 Tahun 2002 tentang Perlindungan Anak.

\section{Motivasi Adopsi dan Perkembangannya}

Adopsi berasal dari kata adoptie, bähasa Belanda atau adopt (adoption) dalam bahasa Inggris yang berarti pengangkatan anak atau mengangkat anak. Dalam bahasa Arab adopsi dikenal dengan istilah "tabann" yang diartikan dengan "mengambil anak angkat". 3 Beberapa pendapat yang ada mengenai adopsi pada garis besarnya dapat diklasifikasikan dalam dua pengertian, pertama, adopsi diartikan sebagai salah satu perbuatan hukum yang berupa pengambilan anak orang lain ke dalam keluarga sendiri sedemikian rupa, sehingga antara orang yang memungut anak dan anak yang dipungut itu timbul suatu hubungan hukum kekeluargaan yang sama seperti anak kandungnya sendiri. Kedua, adopsi diartikan sebagai penyatuan seseorang terhadap anak orang lain ke dalam keluarga, diperlakukan sebagai anak dalam segi kecintaan, kasih sayang, pendidikan dan pelayanan serta pemenuhan segala kebutuhan, akan tetapi tidak diperlakukan sebagai nasabnya. ${ }^{4}$

Adopsi di Indonesia sebenarnya bukan masalah baru, sejak zaman dahulu pengangkatan anak sudah dilakukan dengan cara dan motivasi yang berbeda sejalan dengan sistem hukum dan kenyataan hukum yang tumbuh dan berkembăng dalam masyarakat. Beberapa alasan yang melatarbelakangi seseorang untuk melakukan adopsi adalah:5 Pertama, adanya rasa belas kasihan terhadap anak terlantar atau anak yang orang tuanya tidak mampu memeliharanya. Hal demikian merupakan motivasi yang positif karena selain membantu anak meraih masa depannya juga dapat meringankan

${ }^{3}$ Muderis Zaini, Adopsi Suatu Tinjauan dari Tiga Sistem Hukum (Jakarta: Bina Aksara. 1995), hlm. 4.

4 bid., hlm. 6.

${ }^{5}$ Djaja S. Meliala, Pengangkatan Anak (Adopsi) di Indonesia (Bandung: Tarsito, 1992), hlm. 4. zi: 
beban orang tua kandungnya. Kedua, tidak mempunyai anak, dan ingin memiliki anak yang dapat menjaga dan merawatnya di masa tua. Motivasi ini secara umum biasa dilakukan karena satu-satunya jalan bagi mereka yang tidak mempunyai anak hanyalah dengan cara adopsi, sebagai pelengkap kehidupan rumah tangga suami istri. Keberadaan anak yang demikian bisa menjadi harapan akan keberlangsungan masa tua bagi orang tua angkat. Ketiga, adanya kepercayaan bahwa dengan adanya anak di dalam keluarga akan cepat mendapatkan anak sendiri. Motivasi ini sangat erat kaitannya dengan kepercayaan yang berkembang dalam masyarakat adat. Sebagian masyarakat Indonesia meyakini bahwa dengan cara mengambil anak angkat akan dengan cepat untuk mendapatkan keturunan, sehingga status anak seperti ini sebagai pancingan. Keempat, untuk mendapatkan teman bagi anaknya yang sudah ada. Motivasi ini muncul manakala ada kepastian bagi suami isteri yang tidak dimungkinkan lagi memiliki anak karena berbagai faktor, sementara anak yang telah dimiliki membutuhkan teman sebagai pendamping kehidupannya. Kelima, untuk menambah dan mendapatkan tenaga kerja. Mengambil anak dengan motivasi yang demikian pada awalnya bernilai positif, karena orang tua angkat ingin mẹneruskan usaha yang dimilikinya sementara mereka tidak memiliki anak, akan tetapi dalam perkembangannya motivasi yang demikian bisa menjadi pemicu timbulnya eksploitasi anak dalam bidang ketenagakerjaan, karena keberadaan anak yang masih dini terkadang sudah diminta untuk turut membantu usaha orang tua angkatnya. Keenam, mempertahankan ikatan perkawinan atau kebahagiaan keluarga, manakala orang tua angkat tidak memiliki anak kandung. Masyarakat masih meyakini bahwa kehadiran anak dalam keluarga selain untuk meneruskan keturunan juga berarti sebagai tali yang dapat mempererat jalinan kasih antara suami istri, sehingga setiap pasangan suami isteri akan berupaya secara optimal untuk mendapatkan keturunan tersebut.

Sejalan dengan meningkatnya kebutuhan masyarakat nampaknya motivasi adopsi juga mengalami perkembangan, tidak lagi hanya pada nilai sosial kemasyarakatan yang menjadi motivasinya tetapi sudah mengarah pada faktor ekonomi dan politik. Beberapa peluang yang ada pada bidang ekonomi memungkinkan adanya eksploitasi anak yang berkedok adopsi untuk tujuan yang menyimpang. Salah satu contoh terbukanya peluang eksploitasi anak pada bidang pariwisata yang tertuang dalam Undang-Undang Nomor 9 Tahun 1990.

Pasal 1 Undang-Undang Pariwisata menyatakan bahwa usaha pariwisata adalah kegiatan yang bertujuan menyelenggarakan jasa pariwisata atau menyediakan atau mengusahakan objek dan daya tarik wisata, usaha sarana pariwisata dan usaha lain yang terkait dengan bidang tersebut. Pasal 23 undang-undang tersebut juga menyatakan bahwa salah satu jenis usaha sarana pariwisata adalah penyediaan akomodasi yang meliputi kamar dan "fasilitas lain serta pelayanan yang diperlukan". Istilah "fasilitas lain" yang ada dalam undang-undang tersebut sangat kabur sehingga istilah ini membuka peluang untuk terjadinya penyelewengan dari tujuan pengaturan yang sebenarnya, apalagi jika diperhatikan bahwa bidang pariwisata telah mendapatkan citra yang kurang baik di masyarakat karena identik dengan dunia kesenangan, hiburan dan jasa pelayanan. Jasa 
pelayanan yang ada sebagai salah satu daya tarik pariwisata telah menempatkan anak-anak sebagai objeknya. Jasa ini telah merebak menjadj prostitusi terselubung dengan melibatkan 30\% diantaranya masih berstatus anak. ${ }^{6}$

Dengan melihat realitas di atas adanya pengangkatan anak yang menyimpang dari tujuan yang semestinya dapat berasal dari peluang yang terkandung dalam peraturan perundangan-undangan yang mengandung pengertian kabur. Undang-Undang Pariwisata hanyalah sebagian dari celah yang bisa memunculkan adanya praktik adopsi dengan tujuan yang menyimpang tersebut.

\section{Adopsi sebagai Lembaga Hukum}

Mengacu pada beberapa motivasi adopsi sebagaimana dikemukakan di atas, maka dapat dimengerti bahwa adopsi merupakan suatu lembaga kemasyarakatan yang mempunyai fungsi sosial yang tidak kecil artinya bagi keluarga dan masyarakat keseluruhan. Dalam konteks ini maka adopsi telah menempatkan diri sebagai lembaga yang dibutuhkan masyarakat, dan oleh karenanya diperlukan pengaturan yang jelas demi tercapainya ketertiban dalam mèkanisme pelàksañaannya.

Pengaturan sebagaimana tersebut đỉ ătasdiperlukan karena dalam adopsi paling tidak ada dua kepentingan yang ingin dilindungi, yakni kepentingan orang tua angkat dan kepentingan anak yang akan diangkat. Bagi orang tua angkat akan terjamin kepastian hukumnya terutama terhadap motivasi melakukan adopsi yang ditijnkan oleh pemerintah, sementara bagi kepentingan anak akan lebih terjamin masa depannya terhadap kemungkinan adanya tujuan yang menyimpang dari adopsi yang semestinya. Sebagai suatu lembaga hukum maka kepentingan masyarakat akan terjamin karena misi hukum adalah mempertahankan keteriban dan perdamaian dianitara manusia.

Sebagai suatu lembaga hukum maka adopsi memerlukan landasan hukum sebagai dasar pengaturannya. Bagaimana sebenarnya pengaturan adopsi ini di Indonesia mengingat adopsi ini tidak saja dikenal oleh adat Tionghoa yang kemudian diadopsi oleh hukum Belanda tetapi juga karena pengangkatan anak ini sudah sejak nenek moyang kita-dikeñal dalam lingkungan másyarakat adat. Pengaturan mengenai pengangkatan anak dalam adat Indonesia sangat variatif, tergantung pada sistem kekerabatan yang berlaku dalam wilayah adat tersebut terutama mengenai konsekuensi hukum yang ditimbulkannya. Apabila dalam suatu wilayah adat memberlakukan sistem kekerabatan parental (misalnya Jawa) maka pengangkatan anak tidak otomatis memutuskan tali keluarga antara anak angkat dengan orang tua kandungnya. Anak angkat akan ngangsu sumur loro atau ngombe sumur loro, artinya selain memiliki hubungan hukum dengan orang tua angkat juga hubungan hukum tetap ada dengan orang tua kandungnya. Pāàà šiștên kekerabatan patrelenial (misalnya Bali) pengangkatan mołk membawa konsekuensi hukum lepasnya hubungan hukum antara anak dengan orangtua kandung dan beralih pada orang tua angkat. ${ }^{\text {" }}$

Dalam Hukum Belanda (yang berlaku di wilayah Hindia Belanda berdasarkan asas korkordansi) semula tidak mengenal adopsi.

${ }^{6}$ Kompas, 6 Agustus 2004.

${ }^{7}$ M. Budiarto, Pengangkatan Anak Ditinjau dari SegiHukum(Jakarta:Akademika Pressendo, 1985), him. 27. 
Sebagaimana disinggung di atas, lembaga ini pada awalnya merupakan kebiasaan masyarakat Tionghoa yang mengangkat anak laki-laki sebagai upaya melanjutkan keturunan bagi merekâ yang dalam perkawinannya tidak memiliki anak, selain itu juga aúanya kepercayaan bahwa dengan mengangkat anak akan mampu melestarikan abu para leluhurnya. Realitas yang demikian kemudian direspon oleh pemerintah Belanda dengan mengeluarkan Stb.1917 No.129. Konsekuensi hukum dari adanya adopsi dalam hukum tersebut ditegaskan dalam Pasal 14 Stb 1917 No. 129 yang menyatakan bahwa adopsi tersebut membawa konsekuerisi gugurnya hubungan keperdataan antara keluarga alamiah dengan anak yang diadopsi.

Dalam sistem Hukum Indonesia pengaturan mengenai adopsi dan akibat hukumnya tertuang dalam berbagai peraturan perundang undangan, ${ }^{8}$ yang secara garis besar dapat diuraikan sebagai berikut:

\section{Pihak yang dapat mengajukan adopsi}

a. Pasangan suami isteri

Ketentuan mengenai adopsi anak bagi pasangan suami isteri diatur dalam SEMA No. 6 Tahun 1983 tentang Penyempurnaan SE No. 2 Tahun 1979 tentang Pemeriksaan Permohoināin Pengesahan/Pengangkatan Anak. Selain itu Kepmensos No. 41/HUK KEPNII/1984 tentang Petunjuk Pelaksanaan Perizinan Pengangkatan Anak menegaskan bahwa syarat untuk mendapatkan ijin calon orang tua angkat berstatus kawin dan pada saat pengajuan permohonan pengangkatan anak usia perkawinan sekurang-kurangnya 5 tahun. Keputusan ini berlaku bagi calon anak angkat yang berada dalam asuhan organisasi sosial.

b. Orang tua tunggal

Stb. 1917 No. 129 menegaskan bahwa hanya suami istri atau janda yang diijinkan untuk melakukan adopsi, akan tetapi SEMA No. 6 Tahun 1983 memberi peluang dimungkinkannya pengangkatan anak oleh mereka yang tidak terikat dalam perkawinan yang sah atau mereka yang belum menikah (single parent adoption).

\section{Anak yang diadopsi}

Dalam Stb 1917 No. 129 pengangkatan anak hanya dimungkinkan terhadap anak lakilaki, akan tetapi Yurisprudensi (putusan Pengadilan Negeri Istimewa Jakarta) tertanggal 29 Mei 1963 telah memungkinkan adopsi terhadap anak perempuan.

\section{Tata cara mengadopsi}

Surat Edaran MA No. 6 Tahun 1983 yang mengatur tata cara mengadopsi anak menyatakan bahwa untuk mengádopsi anak terlebih dahiulu mengajukan permohonan pengesahan/ pengangkatan kepada Pengadilan Negeri ${ }^{9}$ di tempat anak yang akan diangkat itu berada. Bentuk permohonan dapat dilakukan secara lisan atau tertulis dan diajukan ke panitera. Permohonan diajukan dan ditandatangani

${ }^{8}$ Lihat Soedharyo Soimin, Himpunan Dasar Hukum Pengangkatan Anak (Jakarta: Sinar Grafika, 2000). Beberapa ketentuan tentang aturan hukum pengangkatan anak terdapat dalam SEMA No. 2 Tahun 1979 tentang Pengangkatan Anak, SEMA No. 6 Tahun 1983 tentang Penyempurnaan SEMA No. 2 Tahun 1979, Keputusan Menteri Sosial RI No. 4 Tahun 1989 tentang Pengangkatan Anak, Keputusan Menteri Sosial RI No. 41/Huk/Kep/II/1984, tanggal 14 Juli 1984 tentang Petunjuk Pelaksanaan Perizinan Pengangkatan Anak.

${ }^{9}$ Dalam perkembangannya permohonan pengangkatan anak diajukan juga ke Pengadilan Agama apabila 
oleh pemohon sendiri atau kuasanya dengan dibubuhi materai secukupnya dan dialamatkan kepada Ketua Pengadilan Negeri yang daerah hukumnya meliputi tempat tinggal atau domisili anak yang akan diangkat. Permohonan berisi tentang motivasi melakukan pengangkatan anak dan penggambaran kemungkinan kehidupan anak pada masa yang akan datang. Dalam melengkapi kepastian tentang isi permohonan ini maka harus disaksikan oleh dua orang saksi yang mengetahui kondisi pemohon untuk menda-patkan kepastian tentang kemampuan mela-kukan pengangktan anak tersebut. Ada beberapa hal yang tidak boleh dicantumkan dalam permohonan pengangkatan anak yakni menambah permohonan lain selain pengesahan atau pengangkatan anak serta adanya pernyataan bahwa anak tersebut akan menjadi ahli dari pemohon. Mengapa? Karena penetapan yang dimintakan kepada Pengadilan harus bersifat tunggal, tidak ada permohonan lain dan hanya berisi tentang penetapan anak tersebut sebagai anak angkat dari pemohon atau berisi pengesahan saja.

\section{Akibat hukum pengangkatan anak.}

Akibat hukum pengangkatan anak berdampak pada hal perwalian dan kewarisan. ${ }^{10}$ Dalam hal perwalian, sejak putusan atau penetapan diucapkan oleh pengadilan maka orang tuâ-angkat menjadi wali dari anak angkat tersebut. Deñgan demikian sejak saat itu segala hak dan kewajiban orang tua kandung beralih pada orang tua angkat, kecuali bagi anak angkat perempuan beragama Islam apabila akan menikah maka yang dapat menjadi wali nikahnya hanyalah orang tua kandungnya atau saudara sedarahnya. Dalam bidang kewarisan, khazanah hukum Indonesia baik hukum adat, barat maupun Islam memiliki ketentuan waris yang berbeda dan ketiganya memiliki kekuatan hukum yang sama artinya seseorang dapat memilih hukum mana yang akan dipakai dalam menyelesaikan masalah kewarisannya. Dengan demikian status anak angkat sebagai ahli waris atau tidak tergantung pada pengaturan dari sistem hukum yang dimaksudkan.

Dalam sistem Hukum Islam di Indonesia, masalah kedudukan anak angkat telah disinggung meskipun secara terbatas dalam Kompilasi Hukum Islam. Kedudukan anak angkat hanya disinggung dalam Pasal 171 huruf $h$ dan Pasal 209. Pasal 171 huruf $h$ menyatakan anak angkat adalah anak yang dalam hal pemeliharaan untuk hidupnya sehari-hari, biaya pendidikan dan sebagainya beralih tanggungjawabnya dari orang tua asal kepada orang tua angkatnya berdasarkan keputusan Pengadilan. Pasal 209 menyatakan bagian anak angkat dalam bidang warisan dibagi menurut ketentuan Pasal 176 sampai dengan Pasal 193 yakni menurut status dan kedudukannya dalam keluarga asal. Hanya

para pihak beragama Islam, meskipun tidak ada pengaturan secara pasti mengenai kewewenangạn absolut dari Pengadilan Agama terhadap masalah tersebut (Lihat Pasal 49 Undang-Undang No. 7 Tahun 1989). Akibat pengaturan yang tidak jelas tersebut maka hakim Pengadilan Agama dituntut oleh undang-undang untuk dapat menyelesaikan permasalahan dimana hukumnya tidak jelas. Sebagai contoh Pengadilan Agama Yogyakarta telah memutus perkara pengangkatan anak dengan Nomor 09/Pdt.P/2000/PA.YK.

${ }^{10}$ Syekh Muhammad Yusuf Qardhawi, Al Halal wa al Haram fil Islam, Alih Bahasa H. Muammal Hamidy (Surabaya: Bina IImu, 1993), hlm. 308. 
saja KHI menambahkan pengaturan dalam Pasal 209 ayat (2) sebagai produk pembaruan hukum Islam di Indonesia bahwa terhadap anak angkat yang tidak mendapat bagian wasiat maka diberikan wasiat wajibah sebanyak-banyaknya $1 / 3$ dari harta warisan orang tua angkatnya.

Ketentuan wasiat wajibah yang diberikan kepada anak angkat.yang tidak mendapat wasiat dari orang tua angkatnya sebagaimana tersebut di atas, dalam pelaksanaannya tetap memperhatikan ketentuan-ketentuannya," yakni: Pertama, Tidak mengubah status anak angkat menjadi anak kandung. Kedua, Tidak memberi kedudukan dan hak untuk mewarisi secara keseluruhan harta peninggalan orang tua angkat. Ketiga, Tidak sama bagian anak angkat dengan bagian anak kandung. Keempat, Anak angkat tidak menghijab ahli waris yang lain. Kelima, bagian anak angkat paling banyak $1 / 3$ bagian.

Dengan demikian $\mathrm{KHI}$ telah menetapkan suatu hak dan kedudukan hubungan kewarisan antara anak angkat dengan orang tua angkat dalam bentuk wasiat wajibah. . Meskipun ketetapan kedudukan dan hak itu diatur secara terbatas, hal itu tidak mengurangi status yang positif secara hukum.

\section{Adopsi dan Undang Undang Perlindungan Anak}

Anak adalah amanah dan karunia Tuhan Yang Maha Esà, yang memiliki harkat dan martabat.sebagai manusia. Anak adalah generasi muda penerus cita-cita perjuangan bangsa yang akan menjamin kelangsungan eksistensi bangsa dan negara pada masa depan. Agar anak kelak mampu memikul tanggung jawab tersebut maka ia perlu mendapat kesempatan yang seluas-luasnya untuk tumbuh dan berkembang, untuk itu perlu dilakukan upaya perlindungan serta untuk mewujudkan kesejahteraan anak dengan memberikan jaminan terhadap pemenuhan hak-haknya tanpa diskriminasi. Demikian kirakira inti dari pertimbangan dikeluarkannya Undang-Undang Nomor 23 Tahun 2002 tentang Perlindungan Anak.

Salah satu upaya untuk melindungi hak-hak anak dan memperhatikan masa depan anak dapat dilakukan dengan pengangkatan anak atau adopsi. Pasal 1 angka 9 Undang-Undang Perlindungan Anak menyatakan bahwa anak angkat adalah anak yang haknya dialihkan dari lingkungan kekuasaan keluarga orang tua, wali yang sah atau orang lain yang bertanggungjawab atas perawatan, pendidikan, dan membesarkan anak tersebut ke dalam lingkungan keluarga orang tua angkatnya berdasarkan putusan atau penetapan pengadilan. Selain mengenal istilah anak angkat, Undang-Undang Perlindungan Anak juga mengenal istilah anak asuh sebagaimana yang diatur dalam Pasal 1 angka 11, yaitu anak yang diasuh oleh seseorang atau lembaga, untuk diberikan bimbingan, pemeliharaan, perawatan, pendidikan, dan kesehatan, karena orang tuanya atau salah satu orang tuanya tidak mampu menjamin tumbuh kembang anak secara wajar. Pengaturan pengangkatan anak secara rinci diatur dalam Pasal 39 yang dapat diuraikan sebagai berikut:

1. Pengangkatan anak hanya dapat

"M. Yahya Harahap, Kedudukan Janda, Duda dan Anak Angkat dalam Hukum Adat (Bandung: Citra Aditya Bakti, 1993), him. 97. 
dilakukan untuk kepentingan yang terbaik bagi anak dan dilakukan berdasarkan adat kebiasaan setempat dan ketentuan peraturan perundang-undangan yang beriaku.

2. Pengangkatan anak sebagaimana dimaksud dalam ayat (1) tidak memutuskan hubungan darah antara anak yang diangkat dan orangtua kandungnya.

3. Calon orang tua angkat harus seagama dengan agama yang dianut oleh calon anak angkat.

4. Pengangkatan anak oleh warga negara asing hanya dapat dilakukan sebagai upaya terakhir.

5. Dalam hal asal usul anak tidak diketahui, maka agama anak disesuaikan dengan agama mayoritas penduduk setempat.

Dalam rangka melindungi hak-hak anak dari tujuan yang menyimpang, UndangUndang Perlindungan Anak telah menetapkan beberapa ketentuan pidana baik yang dilakukan oleh individu maupun oleh korporasi yang diatur dalam Pasal 77 hingga Pasal 90 . Adapun tindak pidana yang diatur dalam ketentuan tersebut pada garis besarnya meliputi:

1. Penelantaran terhadap anak yang mengakibatkan anak mengalami sakit atau penderitaan, baik fisik, mental maupun sosial.

2. Membiarkan anak dalam situasi darurat atau memerlukan pertolongan.

3. Melakukan pengangkatan anak yang bertentangan dengan ketentuan undangundang.

4. Melakukan kekejaman, kekerasan dan ancaman kekerasan atau penganiayaan terhadap anak.

5. Dengan sengaja melakukan kekerasan atau ancaman kekerasan, memaksa anak melakukan persetubuhan dengannya atau dengan orang lain.

6. Perbuatan cabul terhadap anak.

7. Perdagangan anak.

8. Secara melawan hukum melakukan transplantasi organ dan atau jaringan tubuh anak untuk keperluan pihak lain.

9. Dengan tipu muslihat membujuk anak untuk memeluk agama lain yang bukan atas kemauan sendiri.

10. Eksploitasi anak untuk kepentingan ekonomi atau seksual.

11. Melibatkan anak dalam penyalahgunaan, produksi atau distribusi narkotika dan atau psikotropika juga alkohol dan zat adiktif lainnya.

\section{Adopsi dalam Pandangan Islam}

Istilah pengangkatan anak dalam Islam dikenal dengan nama tabanni. Tindakan hukum pengangkatan anak ini banyak juga dilakukan oleh bangsa Arab pada masa jahiliyah. Bahkan dalam praktiknya pernah juga terjadi pada masa Rasulullah.

Dalam sejarahnya Rasulullah sendiri pernah melakukam praktik pengangkatan anak sebelum menerima ke-Rasulan. Pengangkatan anak ini dilakukan terhadap seorang anak yang. bernama Zaid putra Haritsah. Zaid' adalah seorang anak muda yang ditawan sejak masa kecil dalam salah satu penyerbuan jahiliyah, yang kemudian dibeli oleh Hakim bin Hizam untuk diberikan kepada bibinya yang bernama Khodijah, dan selanjutnya oleh Khodijah diberikan kepada Nabi sesudah beliau menikah dengan Nabi. Zaid kemudian dimerdekakan dan diangkat menjadi anak angkat serta diganti nama menjadi Zaid bin Muhammad. ${ }^{12}$ 
Dalam suatu kesempatan Rasulullah pernah mengatakan di hadapan kaum Quraisy bahwa Zaid telah diangkat menjadi anak angkat berhak mendapat warisan dari beliau.

Dalam beberapa waktu berikutnya setelah Muhammad berstatus sebagai Rasulullah maka turuniah ayat yang menegaskan masalah pengangkatan anak tersebut. Apa yang telah dilakukan oleh Rasulullah terhadap tindakan melakukan pengangkatan anak mendapat koreksi dari Allah sebagaimana tertuang dalam Quran surat al Ahzab ayat 4 5 yang artinya:

"...dan Dia tidak menjadikan anak-anak angkatmu sebagai anak kandungmu sendiri. Yang demikian itu hanyalah perkataanmu di mulut saja, dan Allah mengatakan yang sebenarnya dan Dia menunjukkan jalan yang benar."

"Panggilah mereka (anak-anak angkat itu) dengan memakai nama bapak mereka, itulah yang lebih benar menurut Allah, dan jika kamu tidak mengetahui bapak mereka maka panggillah mereka sebagai saudara-saudaramu seagama dan maula-maulamu, dan tidak ada dosa atasmu bila kamu salah dalam hal ini, tetapi yang dosa adalah yang kamu sengaja dengan hati dan niatmu. Dan Allah Maha Pengampun lagi Maha Penyayang".

Sesudah adanya ketentuan Allah tersebut turun pula wahyu yang berkaitan dengan pengaturan waris mewaris bahwa yang masuk daiam kelompok ahli waris ${ }^{13}$ adalah mereka yang: Pertama, Memiliki hubungan darah yang telah ditentukan secara jelas dalam al-Qur'an. ${ }^{14}$ Kedua, memiliki hubungan perkawinan. Ketiga, hubungan persaudaraan..$^{15}$ Keempat, Hubungan kerabat karena sesama hijrah pada permulaan pengembangan Islam, meskipun tidak ada hubungan darah. ${ }^{16}$ Sejak adanya penegasan Allah tersebut maka Zaid bin Muhammad kembali pada nasab semula yakni Zaid bin Haritsah.

Dari ketentuan di atas jelas bahwa yang dilarang oleh Islam dalam pengangkatan anak adalah pengangkatan anak yang berakibat memutus hubungan nasab antara anak angkat dengan orang tua kandungnya. Pelarangan ini dalam pandangan ahli hukum islam berstatus haram dengan alasan: ${ }^{17}$

1. Mencampurbaurkan peraturan Allah di dalam membentuk masyarakat dan keluarga hingga tidak jelas tanggungjawabnya atas setiap hak dan kewajiban. Dalam Islam memutus tali kekeluargaan atau melenyapkannya dilarang oleh Allah apalagi terhadap anak kandungnya dengan alasan apapun. Kedudukan anak dalam keluarga adalah sebagai penyambung tali kasih antara suami dan istri.

2. Merampas hak milik orang lain sedangkan Allah telah membagi rezeki setiap manusia. Allah telah membagi rezeki menurut kebijaksanaanNya yang mengandung arti

12 Ibid., hlm. 307.

${ }^{13}$ Eman Suparman, Intisari Hukum Waris Indonesia(Bandung: Mandar Madju, 1991), hlm. 13.

${ }^{14}$ AlQur'an telah menegaskan bagian masing-masing ahli waris karena adanya hubungan darah yang tertuang dalam Q.S An Nisa' ayat 7, 11, 12, 33 dan 176.

${ }^{15}$ Lihat Q.S al Ahzab ayat 6 yang intinya menyatakan hubungan persaudaraan memiliki hubungan yang penting dalam Kitab Allah dari pada kebanyakan orang mukmin dan orang Muhajirin.

${ }^{16}$ Lihat Q.S al Anfaal ayat 75 bahwa orang-orang yang beriman dan berhijrah serta berperang termasuk dalam satu golongan. 
mendalam bagi manusia, maka tidak ada hak bagi manusia untuk merubah ketentuan-ketentuanNya.

3. Melanggar ketentuan Allah tentang kekeluargaan karena setiap manusia mempunyai kehormatan sendiri dan bergaul sesama mereka dengan sistem hidup yang telah ditentukan oleh Allah. Dengan demikian tindakan mencampuradukkan keluarga yang bukan mahram merupakan perbuatan yang melanggar kesopanan dan kehormatan Islam.

4. Mengambil hak anak-anak kandung baik dalam kasih sayang maupun dalam pembagian harta pusaka. Ketentuan yang telah ditetapkan Allah adalah manusia bertanggungjawab terhadap keluarganya dan harta benda dibagikan terutama untuk anak-anak kandung.

5. Tidak membedakan antara yang halal dengan yang haram karena anak-anak angkat itu dapat dikawini oleh masingmasing ibu dan bapak angkat mereka begitu pula dengan anak-anak kandung dan keluarga mereka.

6. Perkawinan adalah dasar utama untuk mendapatkan keturunan secara sah.

Dengan melihat uraian di atas maka status anak angkat dalam Islam dengan anak angkat dalam ketentuan adat di Indonesia tergambar adanya titik perbedaan yang prinsip, karena akan membawa konsekuensi kedudukan wali dalam perkawinan maupun status sebagai ahli waris dalam hukum kewarisan.

Masalah adopsi dalam Islam sebenarnya telah jelas pengaturannya sebagaimana terurai di atas, akan tetapi dalam mensikapi adopsi anak-anak korban bencana tsunami seakan terdapat persoalan yang mendasar terutama jika dikaitkan dengan adanya keberatan dari berbagai pihak akan adanya larangan adopsi yang diamanatkan oleh pemerintah. Bagaimana sebenarnya umat Islam Indonesia mensikapi hal tersebut?

Agama Islam sebenarnya mendorong seorang muslim untuk memelihara anak orang lain yang tidak mampu, miskin, terlantar tetapi tidak memberikan status yang sama dengan anak kandungnya, sebab Allah telah menentukan hak-hak anak kandung dalam berbagai hal, yaitu: ${ }^{18}$

1. Prioritas dalam menerima harta warisan, karena anak merupakan pihak yang paling dekat dengan ibu bapaknya dan tidak ada pihak lain yang dapat menggeser hak tersebut. Oleh karena itu dalam bidang kewarisan anak termasuk dalam kategori dzawil furud.

2. Adanya larangan yang bermakna haram apabila anak kandung itu dibunuh atas dasar kekhawatiran akan kelaparan. Disinilah kewajiban orang tua terhadap pemenuhan hak-hak anak kandung.

3. Anak kandung, merupakan mahram atau pihak-pihak yang tidak boleh dikawini bagi ibu bapaknya dan ia boleh hidup bersama di dalam satu rumah tangga, sebab batasan aurat mereka dengan sesama mereka berbeda dengan batasan aurat dengan orang lain yang tidak mahram:

4. Ketentuan mengenai perkawinan, perceraian dan adanya anak dengan segala

${ }^{17}$ Fuad Mohd. Fachruddin, Masalah Anak Dalam Hukum Islam (Jakarta: Pedoman Ilmu Jaya, 1985), him. $61-67$.

$18 \mathrm{lbid}, \mathrm{hlm} .53-56$. 
aspeknya telah dijelaskan oleh Aliah secara mendalam dalam Q.S Al Baqarah ayat 221 $-224$.

Dengan demikian pengangkatan anak dalam Islam lebih diorentasikan pada solidaritas sosial yang bemilai pemeliharaan agar kehidupan, pertumbuhan dan pendidikan anak lebih terjamin. Inilah misi keadilan sosial yang diamanahkan syariah islam yang memberi kesempatan bagi setiap muslim untuk mencapai amal kebaikan. Setiap muslim mendapat kesempatan yang sama untuk menghindari predikat sebagai kelompok manusia yang mendustakan agama sebagaimana yang diamanatkan Allah dalam Q.S Al Maa'un yang menegaskan bahwa salah satu kriteria manusia yang mendustakan agama adalah mereka yang membiarkan anak miskin dan menelantarkan anak yatim.

Dalam mensikapi anak-anak korban tsunami diperlukan ketegasan dalam penegakan hukumnya, sebab masalah yang terkait dengan perlindungan akan masa depan anak baik melalui adopsi maupun pengasuhan anak telah jelas aturan hukum dan konsekuensi hukumnya. Dengan demikian adanya kekhawatiran akan adanya penyimpangan daritujuan adopsi terhadap anak-anak korban tsunami antara lain misi pergantian agama, penjualan anak-anak untuk kegiatan-kegiatan asusila dan tindakantindakan pelanggaran hukum lainnya menjadi permasalahan yang semestinya dikembalikan pada aturan-aturan hukum yang berlaku. Masalah penggantian agama misalnya dikembalikan pada Pasal 39 ayat (3) dan (5) yang menegaskan bahwa calon orang tua angkat harus seagama dengan agama yang dianut oleh calon anak angkat. Dalam hal asal usul anak tidak diketahui maka agama disesuaikan dengan agama mayoritas penduduk setempat. Perlindungan anak dalam memeluk agamanya meliputi pembinaan, pembimbingan dan pengamalan ajaran agama bagi anak (Pasal 43 ayat (2).

\section{Simpulan}

Berdasarkan pada uraian di atas dapat disimpulkan bahwa Islam mengenal dua macam pengangkatan anak, pertama, dalam pengertian menjadikannya anak sebagai anak kandung dalam arti mempunyai hak dan kedudukan sebagai anak kandung sebagaimana yang terjadi pada masa jahiliyah. Kedua, pengangkatan anak dalam pengertian pemeliharaan anak dalam arti tidak menjadikannya sebagai anak kandung.

Praktik yang terjadi pada masa jahiliyah tersebut telah terhapus dengan datangnya Isiam berdasarkan surat Al Ahzab ayat 4-5. Islam memperbaruinya dengan cara pengasuhan terutama terhadap anak-anak yatim sebagaimana terdapat dalam surat Al Ma'uun. Praktiknya di Indoneisa, adopsi atau pengangkatan anak juga tidak otomatis membawa konsekuensi akan perubahan status anak tersebut sebagai anak kandung. Status anak angkat mendapat warisan atau tidak tergantung pada sistem hukum yang dipakai dalam menyelesaikan masalah warisan tersebut. Dalam KHI anak angkat bukanlah sebagai ahli waris akan tetapi ia berhak mendapat wasiat wajibah.

Adopsi dalam Undang-Undang Perlindungan Anak dimaksudkan sebagai upaya untukmelindungi hak-hak anak terhadap keberlangsungan masa depannya, hal yang demikian sejalan dengan apa yang telah diamanatkan oleh Al-Quran. 


\section{Daftar Pustaka}

Djaja S. Meliala, Pengangkatan Anak (Adopsi) di Indonesia, Bandung: Tarsito, 1992

Eman Suparman, Intisari Hukum Waris Indonesia, Bandung: Mandar Madju, 1991

Fuad Mohd. Fachruddin, Masalah Anak Dalam Hukum Islam, Jakarta: Pedoman IImu Jaya, 1985

M. Budiarto, Pengangkatan Anak Ditinjau dari Segi Hukum, Jakarta: Akademika Pressendo, 1985

M. Yahya Harahap, Kedudukan Janda, Duda dan Anak Angkat dalam Hukum Adat, Bandung: Citra Aditya Bakti, 1993

Muderis Zaini, Adopsi Suatu Tinjauan dari Tiga Sistem Hukum, Jakarta: Bina Aksara. 1995

Soedharyo Soimin, Himpunan Dasar Hukum Pengangkatan Anak, Jakarta: Sinar Grafika, 2000
Suara Pembaharuan, "Negara Korban Tsunami Waspadai Adopsi Anak," 5 Januari 2005.

Syekh Muhammad Yusuf Qardhawi, Al Halal wa al Haram fil Islam, Alih Bahasa $\mathrm{H}$. Muammal Hamidy, Surabaya: Bina IImu, 1993

Undang-Undang No. 7 Tahun 1989 tentang tentang Peradilan Agama

Keputusan Menteri Sosial RI No. 4 Tahun 1989 tentang Pengangkatan Anak:

Keputusan Menteri Sosial RI No. 41/Huk/Kep/ VII/1984 tentang Petunjuk Pelaksanaan Perizinan Pengangkatan Anak

Putusan Pengadilan Agama Yogyakarta Nomor 09/Pdt.P/2000/PA.YK.

SEMA No. 6 Tahun 1983 tentang Penyempurnaan SEMA No. 2 Tahun 1979 tentang Pengangkatan Anak

Kompas, 5 Januari 2005.

Kompas, 6 Agustus 2004 